\title{
AN AFTERNOON OF BIRDING ON MITLENATCH ISLAND, B.C.
}

\author{
by Wayne Campbell and Ken Kennedy, Burnaby, B.C.
}

Mitlenatch Island is situated in the Strait of Georgia approximately 100 miles north of Vancouver. The island was purchased by the Provincial Government in 1960 and formally desirnated a Nature Park in 1961. Each year since then the Department of Recreation and Conservation has employed students on the island as park naturalists.

Locally, Mitlenatch is known as "the island for the birds." This is not far from the truth as it boasts one of the largest sea-bird nesting colonies along the B.C. coast. Approximately 3000 pairs of Glaucous-winged Gulls, 400 pairs of Pelagic Cormorants, 250 pairs of Pigeon Guillemots, a few pairs of Black Oystercatchers as well as Northwestern Crows and Song Sparrows use the island as a breeding ground.

Most of the island's 88 acres consist of bare rock outcroppings. The shoreline is steep, rugged and exposed. Shrubbery and grassy growth is thick and varied in cracks and fissures containing soil. A small grassy meadow of six and one-half acres, which supports a few groves of lodgepole pine, separates the two rather large rocky hills that form most of the island. One hill, West Hill, attains a height of 175 feet. Because of its position, in the rain shadow of Vancouver Island, Mitlenatch receives little rain. For this reason such typically arid plants as mullein, cactus and wooly sunflower are plentiful.

Birding on Mitlenatch is usually fair to good but on August 24, 1965 we were to enjoy an afternoon seldom experienced by birders on the Pacific Coast.

Around noon we left camp to gather a few oysters for supper. The weather was actually poor. A low mist surrounded the island limiting visibility to just over a mile and a constant drizzle did not help to brighten conditions. Just before we reached the oyster beds two medium-sized gravish birds took to the air, unmistakably Wandering Tattlers. This was not an unusual sighting as "tattlers" are regular visitor's to the island. Feeding in the inter-tidal zone were two regulars, Glaucous-winged Gulls and Northwestern Crows. A closer look revealed three rather large black birds with bright red bills. These were Black Oystercatchers. They were sneaking among the oyster's obviously trying to "catch" a slightly opened shell. Towards the top of the beach three Ruddy Turnstones were busy feeding among a clump of rockweed or Fucus. Just beyond the tide a Double-crested Cormorant seemed to be having difficulty swallowing a freshly caught sculpin. Out from the cormorant an unusually large concentration of Pigeon Guillemots, approximately 150 in all, were busy feeding on a passing school of small fish. These sightings are quite normal for any afternoon on Mitlenatch for this time of year. Soon, however, things were to change. We started towards the pines armed with binoculars and a 25-power 'scope. The sky was still heavily overcast but now finely dotted with many small black objects. After a few minutes the birds came lower and we easily recognized them as swifts. Black and Vaux's were both present but Black were by far the more numerous. Two Band-tailed Pigeons caught our eyes as they quickly flapped past the higher parts of the island. As we neared the grove of pines we noticed a small bird running up, down and around the trunk of the larger pine tree. Soon a brilliantly colored Redbreasted Nuthatch met us. Its antics were quite amusing and it seemed unconcerned at our presence. A glance towards the pine tops revealed 


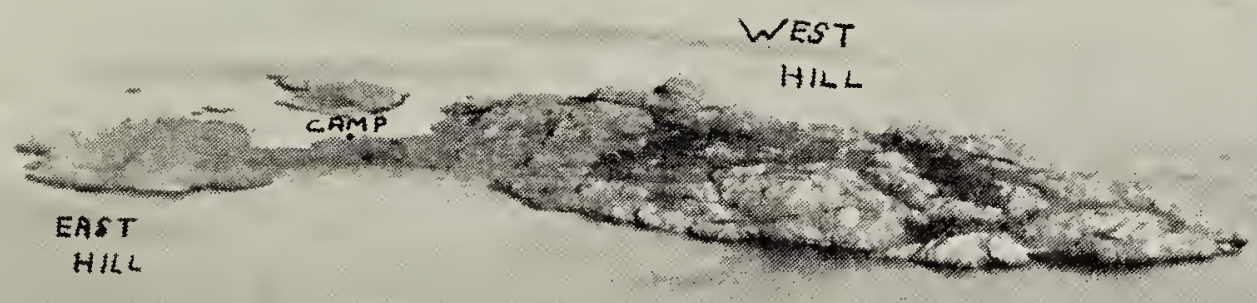

Photo courtesy B.C. Dept. of

Mitlenatch Island

Recreation and Conservation

more activity and it wasn't long before the whole grove of trees seemed to come to life. Wilson's and Magnolia Warblers, a Pine Siskin, a Hutton's Vireo and a Western Wood Pewee were seen and recorded. Among the lower pines were more Wilson's Warblers as well as Song and Lincoln's sparrows. At eye level more new shapes appeared - Violet-green, Rough-winged, Bank and Cliff swallows seemed to be enjoying the recent mosquito hatch. It is interesting to note that Magnolia Warblers and Bank Swallows are considered rarities on the west coast. One and a half hours later we managed to leave the pines and walked over to see what the ocean had to offer.

A small flock of "peeps" (Western and Least sandpipers) signalled our arrival. Rather close to shore a flock of nine immature "bonies" (Bonaparte's Gulls, were swimming contentedly among several immature Glaucous-winged Gulls. Suddenly a flock of 15 Pintail appeared, circled over our heads, but left almost as quickly as they appeared. A quick scan over the water surface with the 'scope helped add two more species to our list. An immature Marbled Murrelet was noticed diving and a bit farther out a flock of 35 Surf Scoters were lazily drifting with the tide currents. The afternoon was almost twothirds gone now so we decided to take a quick trip around one end of the island back towards camp. Roosting along the lower rocks of West Hill were several small flocks of Harlequins, all in eclipse plumage. Resting among the Harlequins were five Black Turnstones. We left the lower beach and started over the hill towards the Pelagic Cormorant colony. A male Brewer's Blackbird took wing from the shrubbery only to be followed by $50+$ Northwestern Crows and $500+$ Starlings. Usually in the late evening hundreds of Starlings arrive from adjacent islands to roost here. During all this commotion we noticed a medium-sized bird leave a tall douglas fir snag not too far from us. Through the binoculars we saw a beautiful male Peregrine Falcon. With this sighting we were dubious if we could add anything new to our afternoon total, but as we progressed towards the Pelagic nesting area we scanned 
a small cormorant roost and noticed a few immature Pelagics, three Double-crested and one Brandt's Cormorant. Neither Double-crested nor Brandt's nest on Mitlenatch but in time may do so. We soon reached the cliffs and watched the black, naked young cormorants feed and scramble about the nest. Just below, feeding among the seaweeds was a Greater and Lesser yellowlegs. As we left the nesting cormorants and neared camp four Spotted Sandpipers (two in nonbreeding plumage) flitted low over the water. Just before camp a dampish, immature Brown-headed Cowbird concluded our afternoon total.
At camp, after a good drying, we tallied the birds we recorded for the afternoon. We found we had recorded 38 species, 14 of which were new summer records and of these, seven were new records for the island. To many, this is not an impressive figure for six hours birding but when one considers that we recorded only 73 species for the entire summer, August 24 was outstanding. A new hatch of mosquitoes, the extremely low tide and the weather conditions no doubt had considerable influence in attracting the birds. August 24 was an excellent day on Mitlenatch and it will probably be some time before such a day will occur again.

\section{VARIED THRUSH CONTINUES TO VISIT REGINA by Frank H. Brazier, Regina}

On October 12,1965 , as I was passing the great Siberian crabapple tree growing at the rear of the Legislative Buildings in Regina, I was overtaken by a flock of perhaps 20 Robins headed for that tree; one of the flock swept past me low and fast and I caught a glimpse of a gray bird with a wing stripe. "Aha," I thought, "a Townsend's Solitaire!" and approached the tree cautiously since I had no binoculars with me. Standing at the tree I examined all the Robins, then noticed a bird at the back, somewhat smaller than the others, with a striking tawny eyebrow line. It graciously moved a little closer and came into the sunlight to show itself to be a Varied Thrush (Ixoreus naevius). This individual did not have the conspicuous black breast band we often associate with the species; however, the bright tawny underparts, throat and cheeks, with the wide tawny eyebrow and wing patches left no doubt as to its identity. It was probably either a young bird or a female.

The Varied Thrush seen in this neighbourhood October 24, 1964 (see Blue J(1y, 22:153) was the first of its species seen in Regina by more than one person the others previously reported having been observed singly by one person on one occasion only, with other observers who looked for it later being unable to find it. I was quite surprised, therefore, when passing the same tree at 9:00 a.m. the following day to find the thrush there feeding on Siberian crabapples. I telephoned Robert Nero, who arrived somewhat later and was also able to see the bird. In the late afternoon of the same day, he pointed the bird out to Dr. J. W. Gerrard, a visitor from Saskatoon, and Margaret Belcher.

Over a week later (October 23, 1965) Margaret Belcher called me to report a second observation of a Varied Thrush, seen in the same location near the Legislative Buildings, flying and resting in the Siberian crabapple and nearby trees. This bird was seen by Margaret and a small group of birders from the Regina Natural History Society who meet in the Legislative Grounds on Saturday afternoons. On the morning of October 24 I was able to see the bird too. We were both struck by the fact that this bird had a much more distinct breast band, and I thought it much brighter in colouring; this suggested to us that it was actually a second Varied Thrush, and probably a male, rather than the bird observed earlier. 